\title{
Molecular analysis of isolates of Streptoccocus suis capsular type 2 by restriction-endonuclease-digested DNA separated on SDS-PAGE and by hybridization with an rDNA probe
}

\author{
Marc Beaudoin, ${ }^{1}$ Josée Harel, ${ }^{1}$ Robert Higgins, ${ }^{1}{ }^{*}$ Marcelo Gottschalk, ${ }^{1}$ \\ Michel FrenetTE ${ }^{2}$ and JANET I. MaCINNES ${ }^{3}$ \\ ${ }^{1}$ Groupe de Recherche sur les Maladies Infectieuses du Porc, Faculté de Médecine Vétérinaire, Université de Montréal, \\ CP 5000, Saint-Hyacinthe, Québec, Canada J2S 7 C6 \\ ${ }^{2}$ Department of Veterinary Microbiology and Immunology, Ontario Veterinary College, University of Guelph, Ontario, \\ Canada NIG 2 Wl \\ ${ }^{3}$ Groupe de Recherche en Écologie Buccale, École de Médecine Dentaire, Département de Biochimie, Université Laval, \\ Ste-Foy, Québec, Canada G1K $7 P 4$
}

(Received II February 1992; revised 22 July 1992; accepted 5 August 1992)

\begin{abstract}
This study was undertaken to assess the discriminatory value of restriction endonuclease (RE) digestion patterns of Streptococcus suis chromosomal DNA using polyacrylamide gel electrophoresis (SDS-PAGE) and DNA-rDNA hybridization. For the RE digestion patterns, DNAs were digested separately with the enzymes BamHI and BglII and the resultant fragments were separated by SDS-PAGE. An Escherichia coli rDNA probe derived from pKK3535 was used for the hybridization. Twenty-three $S$. suis capsular type 2 isolates recovered from diseased and clinically healthy pigs, from a human case, and from a cow were compared in this study. The majority of isolates associated with septicaemia belonged to one restriction endonuclease analysis (REA) profile group. Isolates associated with pneumonia belonged either to the REA profile group of isolates associated with septicaemia or to a second REA profile group. The REA profiles of isolates from clinically healthy animals were more heterogeneous. The REA profile of the type 2 reference strain, $\mathbf{S 7 3 5}$, which was originally isolated from a pig, was very different from those of the porcine and bovine isolates but similar to the profile of the human isolate. The profiles obtained after rDNA hybridization were more homogeneous. Although different patterns were detected in the 23 isolates, there was no correlation between the source of the isolate and the patterns observed with this technique.
\end{abstract}

\section{Introduction}

Streptococcus suis is an important pathogen in the swine industry. This micro-organism causes a variety of infections, including septicaemia, meningitis, arthritis and pneumonia (Higgins et al., 1990b). It has also been associated with different pathologies in ruminants (Higgins et al., 1990a; Hommez et al., 1986) and humans (Arends \& Zanen, 1988; Trottier et al., 1991). To date, 29 different capsular types of $S$. suis have been described (Perch et al., 1983; Gottschalk et al., 1989, 1991 a). S. suis capsular type 2 is thought to be the most virulent serotype and, in most countries, it is the most prevalent capsular type isolated from diseased animals (Hommez et al.,

\footnotetext{
* Author for correspondence.

Abbreviations: RE, restriction endonuclease; REA, restriction endonuclease analysis.
}

1986; Higgins et al., 1990 b, 1992). Nevertheless, capsular type 2 isolates have also been isolated from nasal cavities of clinically healthy pigs (Brisebois et al., 1990).

In the diagnostic laboratory, $S$. suis can be presumptively identified by biochemical tests (Kilpper-Balz \& Schleifer, 1987; Higgins \& Gottschalk, 1990). Confirmation is obtained by capsular typing (Gottschalk et al., 1989). No correlation has been found between biochemical profiles and capsular types, nor can biochemical tests differentiate between strains of the same capsular type. Although some differences in plasmid profiles of isolates of capsular type 2 have been detected, the majority of porcine isolates studied by Cantin et al. (1992) had similar plasmid profiles.

Restriction endonuclease analysis (REA) has been found to be very useful in epidemiological studies of other clinically important bacteria, including Streptococcus species (Skojold et al., 1987; Cleary et al., 1988; 
Martin et al., 1990; MacInnes et al., 1990; Harel et al., 1990). Mogollon et al. (1990) demonstrated differences among some $S$. suis strains of different capsular types using REA. More recently, the same group reported that REA could discriminate between capsular type 2 isolates from various tissues of diseased and clinically healthy animals (Mogollon et al., 1991).

The rRNA operons (including 5S, 16S, 23S and some tRNA genes) are present in several copies in the bacterial chromosome (Normura \& Post, 1980). MoreJver, the use of an rRNA probe for comparative purposes has been demonstrated with various microJrganisms (Chiodini, 1990; Picard et al., 1991). With this :echnique, an electrophoretic pattern which contains numerous restriction fragments is more easily readable. DNA-DNA hybridization with an rRNA gene probe ras also been used to study the distribution of strains in different bacterial species (Grimont \& Grimont, 1986; Jwen, 1989; Stull et al., 1988).

The purpose of this study was to investigate Canadian solates of $S$. suis capsular type 2 associated with tifferent types of infections and from different animal species, in order to determine if different strains were issociated with a particular type of infection. Strains were studied by REA with separation of fragments by SDS-PAGE, which permits better resolution of fragnents than agarose gels electrophoresis, and by hybridizition using an Escherichia coli rDNA probe. Both inalyses were done using two enzymes, BamHI and BglII.

\section{Methods}

Bacterial strains. The reference strain of $S$. suis capsular type 2, S735 (NCTC 10234), and 22 capsular type 2 field isolates were used in this study (see Table 1). All porcine isolates originated from different geographical areas of Canada and the Netherlands and they were selected over a two-year period. The bovine isolate was recovered in pure culture from an aborted cattle foetus submitted to the Faculty of Veterinary Medicine of the University of Montreal. Strain Ar770297, from a case of human meningitis, was generously supplied by J. P. Arends, Groningen, the Netherlands; the capsular type 2 reference strain was kindly supplied by J. Henrichsen of the Statens Seruminstitute, Copenhagen, Denmark. Isolates 2 to 7 were recovered from porcine pneumonia cases and were isolated from lungs in pure culture. Isolates 8 to 15 , associated with septicaemia cases, were isolated from pigs in more than one organ and isolates 16 to 21 originated from nasal swabbings of clinically healthy piglets. All isolates were cultured on bovine blood agar plates (Trypticase soy agar, BBL) at $37^{\circ} \mathrm{C}$ for $18 \mathrm{~h}$. The stock cultures were stored at $-70^{\circ} \mathrm{C}$ in medium containing $5 \%$ (w/v) Dextran T40 (Pharmacia LKB Biotechnology) and 7\% (w/v) sucrose.

Biochemical testing and serotyping. Biochemical tests (growth in 6.5\% $\mathrm{NaCl}$, arginine dihydrolase, production of acetoin, production of acid from lactose, salicin, glycerol, inulin, trehalose, sorbitol, sucrose and mannitol) were performed on the 23 isolates (Higgins et al., 1990b; Hommez et al., 1986). All isolates had the characteristic biochemical profile for $S$. suis (Kilpper-Balz \& Schleifer, 1987) except strain 4/3 HI (no. 17), an isolate from a clinically healthy pig. This organism was mannitol positive. All isolates were then confirmed as capsular type 2 using both the coagglutination and the capsular reaction tests (Higgins \& Gottschalk, 1990).

Isolation of DNA and restriction endonuclease digests. Total cellular DNA was isolated using a modification of the method of Leblanc \& Lee (1979). Cells were grown at $37^{\circ} \mathrm{C}$ in Todd-Hewitt broth (Difco) supplemented with L-threonine and glucose. Three millilitres of a $6 \mathrm{~h}$ culture was used to inoculate $100 \mathrm{ml}$ fresh medium and the culture was incubated in a shaking incubator at 110 r.p.m. Cells were harvested by centrifugation at $10000 \mathrm{~g}$, washed once with $2 \mathrm{M}-\mathrm{NaCl}$ and twice with water. The cells were then resuspended in $8 \mathrm{ml}$ buffer containing $20 \mathrm{mM}$-Tris/ $\mathrm{HCl} \mathrm{pH} 6.9,20 \%(\mathrm{w} / \mathrm{v})$ glucose and $1 \mathrm{mM}-\mathrm{MgCl}_{2} ; 1 \mathrm{ml}$ $0.5 \mathrm{M}$-EDTA $\mathrm{pH} 8.0$ and $1 \mathrm{ml} 1 \mathrm{M}-\mathrm{Tris} / \mathrm{HCl} \mathrm{pH} 8.0$ were added to the cell mixture. Lysozyme $\left(10 \mu \mathrm{g} \mathrm{ml}^{-1}\right)$ was then added and the mixture was incubated for $30 \mathrm{~min}$ at $37^{\circ} \mathrm{C}$. SDS and proteinase $\mathrm{K}$ were added to final concentrations of $2 \%(\mathrm{w} / \mathrm{v})$ and $10 \mu \mathrm{g} \mathrm{ml}^{-1}$ respectively and the mixture was incubated for $1 \mathrm{~h}$ at $50^{\circ} \mathrm{C}$. Following several phenol and chloroform extractions, the DNA was precipitated by the addition of 2.5 vols cold $95 \%(\mathrm{v} / \mathrm{v})$ ethanol. The DNA was then dissolved in TE (10 mM-Tris/HCl, 0.1 M-EDTA, pH 8.0) and treated with RNAase A $\left(10 \mu \mathrm{g} \mathrm{ml}^{-1}\right)$. The concentrations of the DNAs were determined spectrophotometrically (Maniatis et al., 1982). Restriction digests were prepared using $3 \mu \mathrm{g}$ DNA in a total volume of $50 \mu \mathrm{l}$.

Southern blotting. Restriction fragments were separated by electrophoresis in $0.8 \%(\mathrm{w} / \mathrm{v})$ agarose gel in Tris/acetate buffer (40 mM-Tris/ acetate pH 8.3, $2 \mathrm{~mm}$-EDTA) at $30 \mathrm{~V}$ for $16 \mathrm{~h}$. Approximately $2 \mu \mathrm{g}$ of DNA per lane was applied. DRIgest III molecular mass markers (Pharmacia LKB Biotechnology) were included in each gel. The DNA fragments were visualized with ethidium bromide. After electrophoresis, DNAs were transferred to a nylon membrane (Zeta-Probe Membranes, Bio-Rad) for 18 to $24 \mathrm{~h}$ as described previously (Lortie $e t$ al., 1991). E. coli with plasmid pKK3535 was kindly provided by J. Brosius, Harvard University, Boston, MA, USA (Brosius et al., 1981). An rDNA probe comprising a $7.7 \mathrm{~kb}$ fragment containing the $r r n B$ operon encoding tRNA $A_{G l u}, 5 S, 16 S$ and $23 S$ RNA and $\lambda r i f^{d}$ was obtained after cutting the plasmid pKK3535 with BamHI endonuclease. The probe fragment was isolated by gel purification (Maniatis et al., 1982) and end-labelled by random priming (Pharmacia LKB Biotechnology) with $\left[\alpha-{ }^{32} \mathrm{P}\right] \mathrm{dCTP}$. The blots were hybridized overnight and subjected to a stringent wash in $0.2 \times \mathrm{SSC}$ at $50^{\circ} \mathrm{C}$ as described previously (Harel et al., 1991). The $7.7 \mathrm{~kb}$ probe fragment contained lambda $r i f^{\mathrm{d}} 18$ sequences which hydridized to the $9.5 \mathrm{~kb}$ fragment from Lambda DRIgest III molecular mass markers. Isolates with a single band difference were considered to belong to a different group and assigned an arbitrary letter.

Restriction endonuclease treatment and electrophoresis. For restriction endonuclease analysis, fragments were resolved on a $7.5 \%$ SDSpolyacrylamide gel and visualized by silver staining using a modification of the method of Sammons et al. (1981) as described previously (Smart et al., 1988). DNAs were digested separately for $1 \mathrm{~h}$, using a fourfold excess of either BamHI or BglII according to the manufacturer's instructions (Pharmacia LKB Biotechnology). The gels were photographed or stored in $25 \%$ ethanol $10 \%$ acetic acid (v/v). Gels were then inspected visually and each different profile was assigned an arbitrary letter. Isolates with the commonest REA profiles were used as a reference to create different groups. Isolates which had REA profiles that varied by two fragments or less, in comparison to the reference isolate of each group, were considered similar (Kristiansen et al., 1986). REA profiles were determined in at least three independent gels. No attempt was made to include bands larger than $\sim 4 \mathrm{~kb}$ in the analysis, as the separation of such bands was insufficient with the electrophoretic conditions used. 


\section{Results}

\section{Restriction endonuclease analysis}

The $S$. suis field isolates along with reference strain $\mathbf{S} 735$ were analysed using the restriction enzymes $B a m H I$ and $B g l$ II. A good separation of approximately 15 fragments, ranging in size from 1.3 to $3.5 \mathrm{~kb}$, was obtained when DNAs were digested with BamHI, whereas digestion with $B g l$ II gave rise to about 18 fragments, ranging in size from 1.3 to $1.7 \mathrm{~kb}$ (Figs 1 and 2). Although major differences were detected, REA when using BamHI gave bands of approximately $1.5,1.9,2.5$ and $3.0 \mathrm{~kb}$ that were common to all isolates (Fig. $1 b$ ). BglII fragments of about 1.5 and $1.7 \mathrm{~kb}$ were shared by most of the $S$. suis isolates (Fig. $1 a$ ). However, the REA profiles of the type 2 reference strain, $\mathrm{S} 735$, were quite different from those of the swine isolates but similar (Fig. 2) to the human isolate REA profiles. $B g / \mathrm{II}$ profiles of isolates associated
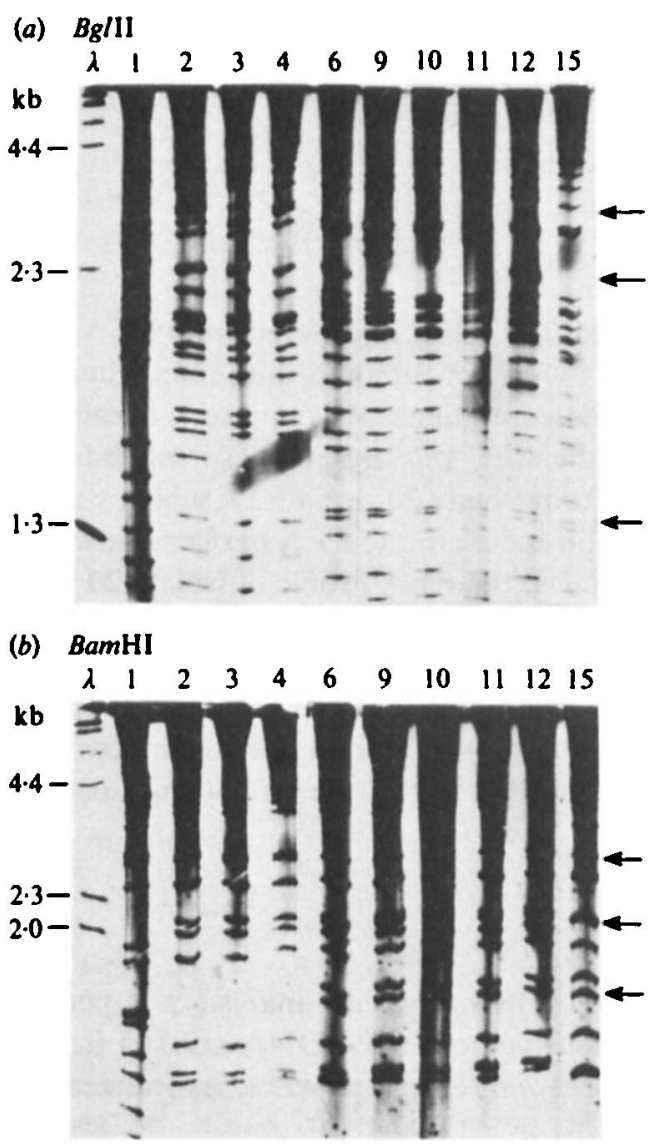

Fig. 1. REA profiles of $B g / \mathrm{II}-(a)$ and with $B a m H I-(b)$ digested DNA of $S$. suis capsular type 2 isolates from pigs with pneumonia (lanes 2-6) and with septicaemia (lanes 9-15). Lanes: 1 , reference strain, S735; 2 , 89.4223 ; 3, EA.0891.90; 4, 90.1330; 6, 89.6891.2; 9, 89.5926; 10, $89.5046 ; 11,90.999 ; 12,90.3363 ; 15,90.176 .6088$. The size of the molecular markers is indicated in $\mathrm{kb}$; the arrows indicate the positions where major differences in the REA profiles were noted.


Fig. 2. REA profiles of BamHI- (a) and BglII- (b) digested DNAs of $S$. suis type 2 isolates. Lanes: 1 , reference strain, $\mathrm{S} 735 ; 17,4 / 3 \mathrm{H} 1 ; 20$, 4/39 H1; 23, AR770297.

(a) $B g \Pi$

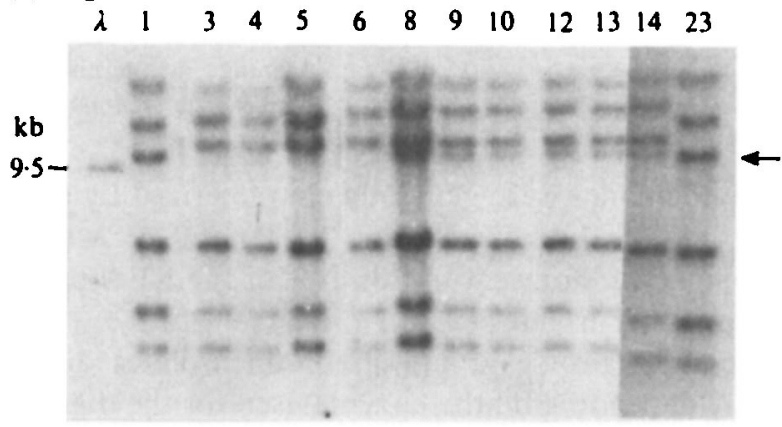

(b) BamHI

$\begin{array}{lllllllllllll}\lambda & 1 & 3 & 4 & 5 & 6 & 8 & 9 & 10 & 12 & 13 & 14 & 23\end{array}$

kb

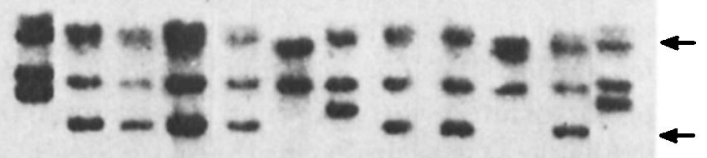

Fig. 3. Southern blot of $B g / \mathrm{II}-(a)$ and $B a m H I-(b)$ digested DNAs from $S$. suis type 2 isolates from pigs with pneumonia (lanes 3-6) and septicaemia (lanes 8-14). The type 2 reference strain (lane 1) and a human meningitis strain (lane 23) are included for comparison. The blots were probed with ${ }^{32} \mathrm{P}$-labelled rDNA probe. 1 , reference strain, S735; 3, EA.0891.90; 4, 90.1330; 5, M89.4671.1; 6, 89.6891.2; 8, LM.90.559; $9,89.5926 ; 10,89.5046 ; 12,90.3363 ; 13,90.4193 ; 14$, $89.1591 ; 23$, AR770297. The size of the molecular markers is indicated in $\mathrm{kb}$; the arrows indicate the positions where major differences in the REA profiles were noted. 
Table 1. Classification of $S$. suis capsular type 2 isolates by REA on SDS-PAGE and hybridization

\begin{tabular}{|c|c|c|c|c|c|c|}
\hline \multirow[b]{2}{*}{ No. } & \multirow[b]{2}{*}{ Strain } & \multirow{2}{*}{$\begin{array}{l}\text { Origin (species*, health } \\
\text { status } \dagger, \text { location) }\end{array}$} & \multicolumn{2}{|c|}{ SDS-PAGE } & \multicolumn{2}{|c|}{ Hybridization } \\
\hline & & & BamHI & $B g l$ II & BamHI & BglII \\
\hline 1 & Reference; S735 & S, mening., Netherlands & $\mathrm{F}$ & $\mathbf{H}$ & $\mathbf{E}$ & C \\
\hline 2 & 89.4223 & S, pneum., Quebec, Can. & A & A & A & $\mathrm{C}$ \\
\hline 3 & EA.0891.90 & S, pneum., Alberta, Can. & $\mathbf{A}^{\prime}$ & $\mathbf{A}^{\prime}$ & A & A \\
\hline 4 & 90.1330 & S, pneum., Alberta, Can. & $A^{\prime}$ & $A^{\prime}$ & A & A \\
\hline 5 & M89.4671.1 & S, pneum., Manitoba, Can. & $A^{\prime}$ & $\mathbf{A}^{\prime}$ & A & A \\
\hline 6 & 89.6891 .2 & S, pneum., Quebec, Can. & $\mathbf{B}^{\prime}$ & $\mathbf{B}^{\prime}$ & A & A \\
\hline 7 & 89.88.377 & S, pneum., Quebec, Can. & $\mathbf{B}^{\prime}$ & $\mathbf{B}^{\prime}$ & NT & A \\
\hline 8 & LM.90.559 & S, septic., Alberta, Can. & B & $\mathbf{B}$ & B & B \\
\hline 9 & 89.5926 & S, septic., Quebec, Can. & B & $\mathbf{B}^{\prime}$ & $\mathrm{C}$ & B \\
\hline 10 & 89.5046 & S, septic., Quebec, Can. & B & B & A & B \\
\hline 11 & 90.999 & S, septic., Quebec, Can. & B & $\mathbf{B}^{\prime}$ & A & B \\
\hline 12 & 90.3363 & S, septic., Quebec, Can. & $\mathbf{B}^{\prime}$ & $\mathbf{B}^{\prime}$ & $\mathbf{A}$ & B \\
\hline 13 & 90.4193 & S, septic., Quebec, Can. & $\mathbf{B}^{\prime}$ & B & B & B \\
\hline 14 & 89.1591 & S, septic., Quebec, Can. & $\mathrm{C}$ & $\mathbf{B}^{\prime}$ & $\mathbf{A}$ & B \\
\hline 15 & 90.176 .6088 & S, septic., Quebec, Can. & $\mathbf{B}^{\prime}$ & $\mathrm{C}$ & NT & NT \\
\hline 16 & $4 / 40 \mathrm{H} 2$ & S, healthy, Quebec, Can. & C & D & B & B \\
\hline $17 \ddagger$ & $4 / 3 \mathrm{HI}$ & S, healthy, Quebec, Can. & $\mathrm{E}$ & $\bar{D}^{\prime}$ & $\mathrm{D}$ & D \\
\hline 18 & $11 / 16 \mathrm{Hl}$ & S, healthy, Quebec, Can. & $\mathrm{C}$ & $\mathrm{D}^{\prime}$ & A & $\mathbf{B}$ \\
\hline 19 & $9 / 13 \mathrm{Hl}$ & S, healthy, Quebec, Can. & $\mathrm{C}$ & $\mathrm{D}^{\prime}$ & B & B \\
\hline 20 & $4 / 39 \mathrm{HI}$ & S, healthy, Quebec, Can. & C & $\mathrm{E}$ & B & $\mathbf{B}$ \\
\hline 21 & $4 / 34 \mathrm{Hl}$ & S, healthy, Quebec, Can. & D & $\mathrm{D}^{\prime}$ & NT & NT \\
\hline 22 & 90.741 & B, septic., Quebec, Can. & $\mathrm{C}$ & $\mathbf{F}$ & NT & B \\
\hline 23 & Ar770297 & $\vec{H}$, mening., Netherlands & $\mathrm{F}$ & G & $\mathrm{E}$ & $\mathrm{C}$ \\
\hline
\end{tabular}

NT, Not tested.

* S, swine; B, bovine; $\mathrm{H}$, human.

$\dagger$ Mening., meningitis; pneum., pneumonia; septic., septicaemia.

$\ddagger$ This isolate was mannitol positive.

with pneumonia were generally characterized by only a single band in $1.4 \mathrm{~kb}$ area (Fig. $1 a$, lanes 2-6); whereas two bands were present in this area of the REA profiles of most other isolates (Fig. 1a, lanes 9-15).

The REA profile groupings of the isolates differed slightly depending on the enzyme used for the digestion (Table 1). All the septicaemia isolates were similar to one another. Even though they were from different geographical regions, most of these isolates belonged to $B a m H I$ group B and $B g l$ II group B. The majority of the pneumonia isolates belonged to BamHI group A and $B g /$ II group A. Two pneumonia isolates (nos 6 and 7) had the same pattern as the majority of the septicaemia isolates (group B). The classification with BamHI of isolates associated with porcine septicaemia or pneumonia (Table 1) was similar to that with $B g l \mathrm{lI}$, with the exception of isolates 14 and 15 . The $B g$ III REA profiles of isolate 22, associated with bovine septicaemia, and isolate 20 , from a clinically healthy pig, were different from those of the other isolates. The BamHI REA of isolate 22 was similar to that of isolates from clinically healthy pigs. The REA profiles of isolates from Alberta (nos 3, 4 and 8) and from Manitoba (no. 5) were all identical or very similar to those from Quebec (Table 1).

REAs of two isolates from clinically healthy pigs (nos 17 and 20), and of a human case (no. 23), when cut with
BamHI and BglII (Fig. 2) differed from REAs of isolates associated with pneumonia and septicaemia. With BamHI, the commonest REA pattern obtained for the clinically healthy pig isolates corresponded to that obtained from isolate 20 ; isolate 17 , which was mannitol positive, showed a unique REA pattern. However, when cut with $B g l$ II, the REA profile of isolate 20 was unique and isolate 17 represented the commonest REA pattern for isolates from clinically healthy pigs. Two isolates from the Netherlands, human isolate 23 and the reference strain, no. 1, had identical BamHI profiles but their profiles were different when cut with $B g l \mathrm{II}$ (Table 1).

\section{Ribosomal probe hybridization}

DNA-rDNA hybridization analysis was performed on all isolates using an $E$. coli rDNA derived from plasmid pKK3535. BamHI digests when hybridized with this $r r n B$ probe generated four bands or less, ranging approximately from 9.5 to $30 \mathrm{~kb}$ (Fig. $3 b$ ). In BamHIdigested DNAs, a band of about $12 \mathrm{~kb}$ was present in all isolates except no. 17 (data not shown). Based on their pattern of BamHI bands, isolates could be assigned to one of five hybridization groups (Table 1). The majority of isolates fell into groups A and B, however. Similarly, 
when DNAs were digested with $B g l I I$, four major groups could be observed, although more bands were observed (Table 1). Differences between these groups were very minor. The difference between groups of isolates using $B g l \mathrm{II}$ was located approximately in the $10.0 \mathrm{~kb}$ area and it could be observed as a single or double band (Fig. $3 a$ ). Hybridization after BamHI digestion did not allow differentiation of the isolates according to their origin; but using $B g l \mathrm{II}$, it was possible to group almost all isolates associated with pneumonia and to discriminate them from the others (Table 1). The isolates from healthy animals were more heterogeneous than those from diseased animals (Table 1). The human isolate 23 and the reference strain (S735) formed separate groups when cut with either enzyme; the mannitol-positive isolate 17 represented another separate group when cut with either enzyme.

\section{Discussion}

Restriction endonuclease analysis of genomic DNA is a well-established technique for studying the epidemiology of bacterial infections (Owen, 1989). SDS-PAGE of DNA, combined with silver staining, has also been used to examine some bacteria (Smart et al., 1988). Several studies have also demonstrated that hybridization can be useful to classify species and subspecies (Stull et al., 1988) and to characterize virulent strains (Picard et al., 1991). This technique has already been used to compare strains from other streptococcal species (Cleary et al., 1988; Martin et al., 1990). Chromosomal restriction endonuclease analysis on agarose gel has been used to study S. suis DNA (Mogollon et al., 1990) and it was used to detect epidemiological markers and to evaluate the relationships among strains (Mogollon et al., 1991).

The comparison of the restriction patterns showed a genetic diversity within $S$. suis isolates belonging to capsular type 2 . This diversity within a given capsular type had already been observed for $S$. suis capsular type 2 (Mogollon et al., 1990), as well as with other organisms (Skojold et al., 1987). Our results showed that chromosomal DNA cut with BamHI or BglII gave sufficient fragments on SDS-PAGE to allow genotype comparison and epidemiological differentiation of isolates. The use of SDS-PAGE analysis and silver staining allows good pattern resolution (Hendrix et al., 1991). Because the technique is highly sensitive, isolates within a group and isolates from different groups are easily distinguishable (Figs 1 and 2). Moreover, more differences could be detected among isolates because two enzymes were used instead of only one.

The role of $S$. suis as an emerging or synergistic pathogen in causing specific infections remains unclear.
The REA profiles permitted the allocation of isolates associated with different types of infection into groups. Isolates associated with septicaemia belonged to one REA profile group. Isolates associated with pneumonia belonged either to the REA profile group of isolates associated with septicaemia, or to a second REA profile group. Our results, along with those of Mogollon et al. (1990), suggest either a clonal association or the possibility that some strains have the capacity to cause either meningitis or pneumonia or both. Although the sample size was small, these data are consistent with the notion that there are limited numbers of pathogenic clones associated with pneumonia and septicaemia in virulent $S$. suis isolates. It is interesting that strains associated with meningitis and pneumonia from different geographical regions of Canada and isolated at different times had similar REA profiles. In contrast, several different $S$. suis type 2 classes associated with meningitis and with pneumonia were found among the pig population of South Dakota (Mogollon et al., 1990).

The hybridization of BamHI and BglII fragments with a probe of the $r r n B$ operon reduced the number of visible fragments, thereby making comparisons easier. The hybridization of $S$. suis showed great homogeneity, with only slight variation in the patterns, and this variation was independent of the origin of the isolates. Because of the low number of bands obtained, analysis was easier; nevertheless, some differences could be missed. Hybridization using BamHI restriction did not allow differentiation of the isolates according to their origin; but using $B g l \mathrm{II}$, it was possible to separate almost all isolates associated with pneumonia from the others. Thus, the choice of enzyme for hybridization may be critical to the divergence of patterns. However, when comparing REA profiles obtained by SDS-PAGE and by hybridization it can be concluded that SDS-PAGE allows a finer differentiation between isolates, and the homogeneity found by hybridization suggests that the isolates are genetically similar. The techniques are complementary and each of them can reveal differences not seen by the other.

Isolates from clinically healthy pigs had more heterogeneous REA profiles that were different from those of isolates associated with diseased animals. The isolate from the human case of septicaemia was found to be similar to the reference strain by both REA fingerprinting and hybridization techniques. Both these strains were isolated from the Netherlands; this could explain their similarity. However, Mogollon et al. (1990) also compared human isolates originating from Hong Kong to the same capsular type 2 reference strain as used here, and they obtained very similar patterns even when using the endonuclease HaeIII. Strikingly, porcine isolates showed REA patterns on SDS-PAGE and after hybrid- 
ization different from those of the reference strain and of the human isolate.

Isolate 17 was the only one that tested mannitolpositive, and it had a unique REA pattern. It was classified into a different group from the other isolates. Such biochemically variant isolates have previously been described for capsular type 2 (Hommez et al., 1986) and for capsular types 17, 19 and 21 (Gottschalk et al., $1991 b$ ), but no relationship has yet been demonstrated among these atypical strains and their genomic profiles. The observation that the bovine isolate, no. 22 , had an REA profile similar to that of porcine isolates suggests that $S$. suis could be transmitted from one species to another. In this particular case, the cow had been transported in a truck that had been used earlier to carry pigs.

This study has shown that REA by SDS-PAGE and hybridization could be useful for the differentiation and identification of $S$. suis. REA of $S$. suis isolates by SDSPAGE appears to be a good tool for epidemiological studies whereas DNA-rDNA hybridization seems to be more applicable to taxonomic studies of $S$. suis capsular type 2.

We thank Guy Gagnon from the Groupe de Recherche en Ecologie Buccale of the University of Laval, Quebec, Canada, for his helpful advice.

\section{References}

ARENDS, J. P. \& ZANEN, H. C. (1988). Meningitis caused by Streptococcus suis in humans. Reviews of Infectious Diseases 10 , 131-137.

Brisebois, L., Charlebois, R., Higgins, R. \& Nadeau, M. (1990). Prevalence of Streptococcus suis in four to eight week old clinically healthy piglets. Canadian Journal of Veterinary Research 54, 174-177.

Brosius, J., Ullrich, A., Raker, M. A., Gray, A., Dull, J. D., Gutell, R. R. \& Noller, H. F. (1981). Construction and fine mapping of recombinant plasmids containing the $r r n \mathrm{~B}$ ribosomal operon of E. coli. Plasmid 6, 112-118.

Cantin, M., Harel, J., Higgins, R. \& Gottschalk, M. (1992). Antimicrobial resistance patterns and plasmid profiles of Streptococcus suis isolates. Journal of Veterinary Diagnostic Investigation 4, 170-174.

CHIOdINI, R. J. (1990). Characterization of Mycobacterium paratuberculosis and microorganisms of the Mycobacterium avium complex by restriction polymorphism of the rRNA gene region. Journal of Clinical Microbiology 28, 489-494.

Cleary, P. P., Kaplan, E. L., Livdahl, C. \& Skojold, S. (1988). DNA fingerprints of Streptococcus pyogenes are $M$ type specific. Journal of Infectious Diseases 158, 1317-1323.

Gottschalk, M., Higgins, R., Jacques, M., Mittal, K. R. \& HENRICHSEN, J. (1989). Description of 14 new capsular types of Streptococcus suis. Journal of Clinical Microbiology 27, 2633-2636.

Gottschalk, M., Higgins, R., Jacques, M., Beaudoin, M. \& HeNRICHSEN, J. (1991a). Characterization of six new capsular types (23 through 28) of Streptococcus suis. Journal of Clinical Microbiology 29, 2590-2594.

Gottschalk, M., Higgins, R., Jacques, M., Beaudoin, M. \& HENRICHSEN, J. (1991 $b$ ). Isolation and characterization of Streptococcus suis capsular types 9-22. Journal of Veterinary Diagnostic Investigation 3, 60-65.
Grimont, F. \& Grimont, P. A. D. (1986). Ribosomal ribonucleic and gene restriction patterns as potential taxonomic tools. Annales de l'Institut Pasteur/Microbiologie 137B, 165-175.

HAREL, J., Cote, S. \& JACQUES, M. (1990). Restriction endonuclease analysis of porcine Pasteurella multocida isolates from Quebec. Canadian Journal of Veterinary Research 54, 422-426.

Harel, J., Lapointe, H., Fallara, A., Lortie, L.-A., Bigras-Poulin, M., LARIVIERE, S. \& FAIRBROTHER, J. M. (1991). Detection of genes for fimbrial antigens and enterotoxins associated with Escherichia coli serogroups isolated from pigs with diarrhea. Journal of Clinical Microbiology 29, 745-752.

Hendrix, L. R., Samuel, J. E. \& Mallavia, L. P. (1991). Differentiation of Coxiella burnetii isolates by analysis of restrictionendonuclease-digested DNA separated by SDS-PAGE. Journal of General Microbiology 137, 269-276.

Higgins, R. \& GotrschalK, M. (1990). An update on Streptococcus suis identification. Journal of Veterinary Diagnostic Investigation 2 , 249-252.

Higgins, R., Gottschalk, M., Fecteau, G., Sauvageau, R., Deguise, S. \& Dutremblay, D. (1990a). Isolation of Streptococcus suis from cattle. Canadian Veterinary Journal 31, 529.

Higgins, R., Gottschalk, M., Mitral, K. R. \& Beaudoin, M $(1990 b)$. Streptococcus suis infections in swine. A 16 month study. Canadian Journal of Veterinary Research 54, 170-173.

Higgins, R., Gottschalk, M., Beaudoin, M. \& Rawluk, S. (1992). Distribution of Streptococcus suis capsular types in Québec and Western Canada. Canadian Veterinary Journal 33, 27-30.

Hommez, J., Devriese, L. A., Henrichsen, J. \& Castr yCK, F. (1986). Identification and characterization of Streptococcus suis. Veterinary Microbiology 11, 349-355.

KilPPER-BALZ, R. \& SchleIfER, K. H. (1987). Streptococcus suis sp. nov., nom. rev. International Journal of Systematic Bacteriology 37, $160-162$.

Kristiansen, B. E., Sorensen, B., Bjorvatn, B., Falk, E. S., Fosse, E., Bryn, K., Froholm, L., Gaustad, P. \& Boure, K. (1986). An outbreak of group B meningoccoccal disease: tracing the causative strain of Neisseria meningitidis by DNA fingerprinting. Journal of Clinical Microbiology 23, 764-767.

Leblanc, J. D \& LeE, L. N. (1979). Rapid screening procedure for detection of plasmids in streptococci. Journal of Bacteriology 140, $1112-1115$.

LORTIE, L.-A., Dubreuil, J. D. \& HARel, J. (1991). Characterization of Escherichia coli strains producing heat-stable enterotoxin b (STb) isolated from humans with diarrhea. Journal of Clinical Microbiology 29, 656-659.

Maniatis, T., Fritsch, E. F. \& SambrooK, J. (1982). Molecular Cloning: a Laboratory Manual. Cold Spring Harbor, NY: Cold Spring Harbor Laboratory.

MacInNes, J. I., BORR, J. D., Massoudi, M. \& Rosendal, S. (1990). Analysis of southern Ontario Actinobacillus (Haemophilus) pleuropneumoniae isolates by restriction endonuclease fingerprinting. Canadian Journal of Veterinary Research 54, 244-250.

Martin, N. J., Kalpah, E. L., Gerber, M. A., Menegus, M. A., Randolph, M., Bell, K. \& Cleary, P. (1990). Comparison of epidemic and endemic group $\mathrm{G}$ streptococci by restriction enzyme analysis. Journal of Clinical Microbiology 28, 1881-1886.

Mogollon, J. D., Pijoan, C., Murtaugh, M. P., Kaplan, E. L., Collins, J. E. \& Cleary, P. P. (1990). Characterization of prototype and clinically defined strains of Streptococcus suis by genomic fingerprinting. Journal of Clinical Microbiology 28, 2462-2466.

Mogollon, J. D., Pijoan, C., Murtaugh, M. P., Collins, J. E. \& Cleary, P. P. (1991). Identification of epidemic strains of Streptococcus suis by genomic fingerprinting. Journal of Clinical Microbiology 29, 782-787.

NoRmURA, M. \& Post, L. E. (1980). Organisation of ribosomal genes and regulation of their expression in Escherichia coli. In Ribosomes. Structure, Function and Genetics, pp. 678-691. Edited by G. Chambliss, G. Graven, K. Davis, L. Cahan \& M. Normura. University of Baltimore Press.

OwEN, R. J. (1989). Chromosomal DNA fingerprinting: a new method of species and strain identification applicable to microbial pathogens. Journal of Medical Microbiology 30, 89-99. 
Perch, B., Pedersen, K. B. \& Henrichenen, J. (1983). Serology of capsulated streptococci pathogenic for pigs: six new serotypes of Streptococcus suis. Journal of Clinical Microbiology 17, 993-996.

Picard, B., Picard-Pasquier, N., Krishnamoorthy, R. \& Goullet, P. H. (1991). Characterization of highly virulent Escherichia coli strains by ribosomal DNA restriction fragment length polymorphism. FEMS Microbiology Letters 82, 183-188.

Sammons, D. W., Adams, L. D. \& Nishizawa, E. E. (1981). Ultrasensitive silver-based color staining of polypeptides in polyacrylamide gels. Electrophoresis 2, 135-141.

Skojold, S. A., Quie, P. G., Fries, L. A., Barnham, M. \& Cleary, P. P. (1987). DNA fingerprinting of Streptococcus zooepidemicus
(Lancefield group C) as an aid to epidemiological study. Journal of Infectious Diseases 155, 1145-1150.

Smart, N. L., Miniats, O. P. \& Macinnes, J. I. (1988). Analysis of Haemophilus parasuis isolates from southern Ontario swine by restriction endonuclease fingerprinting. Canadian Journal of Veterinary Research 52, 319-324.

Stull, T. L., Lilipuma, J. J. \& Edlind, T. D. (1988). A broadspectrum probe for molecular epidemiology of bacteria: ribosomal RNA. Journal of Infectious Diseases 157, 280-286.

Trottier, S., Higgins, R., Brochu, G. \& Gottschalk, M. (1991). A case of human endocarditis due to Streptococcus suis in North America. Reviews of Infectious Diseases 13, 1251-1252. 